\title{
PENGUJIAN STRUKTUR FAKTOR PADA KONSTRUK BECK SCALE FOR SUICIDE IDEATION DENGAN INDIVIDU DEWASA AWAL
}

\section{Verisca Marciana Kesuma ${ }^{1}$, Ediasri Toto Atmodiwirjo (Almh) ${ }^{2}$, Rita Markus Idulfilastri ${ }^{3}$}

\author{
${ }^{1}$ Program Studi Magister Psikologi Profesi, Universitas Tarumanagara Jakarta \\ Email: verisca.717182002@stu.untar.ac.id \\ ${ }^{2}$ Fakultas Psikologi, Universitas Tarumanagara Jakarta \\ ${ }^{3}$ Fakultas Psikologi, Universitas Tarumanagara Jakarta \\ Email: ritamarkus@fpsi.untar.ac.id
}

Masuk : 26-03-2021, revisi: 05-10-2021, diterima untuk diterbitkan : 29-10-2021

\begin{abstract}
WHO called suicide become a global phenomenon. There are at least 800,000 people who commit suicide each year or at least one death every 40 seconds. In fact, 79\% of suicide occur in low and middle income countries from ages 15-29. Suicides have also increased in Indonesia at least in January to September 2019 by 302 cases. According to Beck et al. individuals who want to commit suicide are preceded by the suicide ideation so its appropriate to assess suicide in predicting suicide risk later in life. According to Beck et. al. it's appropriate to assess suicide ideation to predicting suicide risk in the future. Scale For Suicide Ideation (BSS) is one of the measuring tools to assess someone's suicide ideation by Beck et al. Some researchers in Indonesia use or refer to indicators in BSS. There are 4 studies that use BSS. 2 of them, use three indicators, 1 of them use five indicators, and other only use BSS without mentioning the indicator. Based on this, researchers want to test the factor structure of the construct in BSS. Participants in this study were 158. The results obtained from testing the factor structure are that there are 3 indicators with the model classified as fit. The first indicator has 10 significant items, the second indicator has 6 significant items, while the third indicator has 3 significant items.
\end{abstract}

Keywords: Suicide ideation, early adulthood, BSS, factor structure

\begin{abstract}
ABSTRAK
WHO menyebutkan bunuh diri menjadi suatu fenomena yang global. Terdapat setidaknya lebih dari 800 ribu orang yang melakukan bunuh diri tiap tahunnya atau setidaknya 1 kematian setiap 40 detik. Faktanya $79 \%$ bunuh diri terjadi pada negara-negara dengan pendapatan rendah dan menengah dari usia 15-29 tahun. Kasus bunuh diri juga bertambah di Indonesia setidaknya pada Januari sampai September 2019 sebanyak 302 kasus. Menurut Beck et al. individu yang ingin bunuh diri didahului oleh ide untuk bunuh diri sehingga tepat untuk menilai bunuh diri dalam memprediksi risiko bunuh diri di kemudian hari. Scale for Suicide Ideation (BSS) merupakan salah satu alat ukur untuk menilai ide bunuh diri seseorang yang disusun oleh Beck et al. Beberapa peneliti di Indonesia menggunakan atau mengacu pada indikator dalam BSS. Terdapat 4 penelitian yang menggunakan BSS, 2 diantaranya menggunakan tiga indikator, 1 peneliti menggunakan lima indikator dan yang lainnya hanya menggunakan alat ukur BSS tanpa menyebutkan indikator yang digunakan. Berdasarkan hal ini, peneliti ingin menguji struktur faktor pada konstruk BSS. Partisipan dalam penelitian ini sebanyak 158 partisipan. Hasil yang didapatkan dari pengujian struktur faktor adalah terdapat 3 indikator dengan model yang tergolong fit. Indikator pertama memiliki 10 butir yang signifikan, indikator ke 2 memiliki 6 butir yang signifikan, sedangkan indikator ke 3 memiliki 3 butir yang signifikan.
\end{abstract}

Kata Kunci: Ide bunuh diri, dewasa awal, BSS, struktur faktor

\section{PENDAHULUAN}

\section{Latar Belakang}

WHO (World Health Organization atau Organisasi Kesehatan Dunia) menyebutkan bunuh diri sebagai suatu fenomena global atau merupakan masalah kesehatan masyarakat secara global (dalam CNN Indonesia, 2019). WHO juga mencatat terdapat setidaknya lebih dari 800 ribu orang yang melakukan bunuh diri tiap tahunnya atau setidaknya satu kematian setiap 40 detik (dalam Susilawati, 2018). Faktanya adalah sebesar $79 \%$ bunuh diri terjadi pada negara-negara dengan pendapatan rendah dan menengah pada tahun 2016. Bahkan, bunuh diri menjadi faktor penyebab 
kematian ke-18 di dunia pada tahun 2016, karena 1,4\% kematian di seluruh dunia disebabkan oleh bunuh diri yang apabila dilihat dari usia yakni berusia 15-29 tahun (Damarjati, 2019).

Salah satu negara yang sedang berkembang adalah Indonesia. Seorang psikiater FKUI-RSCM, Dr dr Nurmiati Amir, SpKJ (K) mengatakan (dalam Susilawati, 2018) menurut WHO, angka bunuh diri di Indonesia pada tahun 2010 sebesar 1,8 per 100 ribu jiwa atau sekitar 5.000 orang per tahun. Pada tahun 2012 meningkat menjadi 4,3 per 100 ribu jiwa atau sekitar 10 ribu per tahun. Pada tahun 2016, meningkat sebanyak 5,2\%. Selain itu, bunuh diri merupakan penyebab kematian ketiga di dunia pada individu yang berusia 10 sampai 24 tahun sehingga mengakibatkan 4.600 jiwa hilang setiap tahun. Menurut Jayani (2019) di Indonesia pada tahun 2017 angka bunuh diri menjadi 8,09 orang per 100 ribu penduduk. Serta pada tahun 2015, BPS (Badan Pusat Statistik) (dalam Databoks, 2016) mencatat setidaknya ada 812 kasus bunuh diri di seluruh wilayah Indonesia.

Berdasarkan catatan WHO (dalam Adzkia, 2019), mengatakan bahwa setidaknya satu orang Indonesia bunuh diri tiap satu jam. Angka ini membuat Indonesia menempatkan urutan 103 dari 183 negara dan urutan ke-9 di ASEAN. Bunuh diri menjadi fokus pada saat ini. David Klonsky dan May (2015) menuntut pemahaman yang lebih dalam mengenai proses dasar yang memunculkan ide bunuh diri, serta upaya yang berakhir dengan kematian. Proses dasar yang memunculkan ide bunuh diri dapat mengembangkan strategi untuk pencegahan bunuh diri, serta dalam mengembangkan intervensi.

Menurut Beck et al. (1979), individu yang memiliki ide bunuh diri merupakan individu yang pada saat ini memiliki rencana dan berkeinginan untuk bunuh diri namun belum pernah melakukan upaya bunuh diri. Hal ini dikarenakan ide bunuh diri secara logikanya muncul terlebih dahulu sebelum adanya upaya bunuh diri atau melakukan bunuh diri. Sehingga, tepat untuk menilai ide bunuh diri dalam memprediksi risiko bunuh diri di kemudian hari (Beck et al., 1979).

Oleh karena itu, Perlman et al. (2011) membuat panduan risiko bunuh diri yang berjudul Suicide Risk Assessment Guide: A Resource for Health Care Organizations Toronto yang berisi mengenai panduan yang telah terstandarkan untuk menilai risiko bunuh diri. Menurut Reynolds (1991), ide bunuh diri secara tradisional telah dikaitkan dengan gangguan afektif seperti major depressive disorder. Berdasarkan laporan WHO (dalam Adzkia, 2019), salah satu pemicu bunuh diri adalah depresi.

Berdasarkan DSM V (American Psychiatric Association, 2013) simtom bunuh diri atau ide bunuh diri menjadi salah satu dari 9 simptom bagi individu yang didiagnosis major depressive disorder. Salah satu simtomnya adalah munculnya pikiran yang berulang mengenai kematian atau munculnya ide bunuh diri, rencana bunuh diri atau berkomitmen untuk bunuh diri. Dalam penelitian yang dilakukan oleh Beck et al. (1993) ditemukan bahwa depresi dapat memperkirakan individu memiliki ide bunuh diri sebesar 2,5 kali lebih besar dari pada diagnosis gangguan mood lainnya. Pada penelitian yang dilakukan oleh Beck et al., (1979), didapatkan penemuan bahwa individu yang memiliki ide bunuh diri juga didiagnosis memiliki gangguan major depressive disorder.

Salah satu alat ukur yang dapat mengetahui ide bunuh diri adalah alat ukur yang disusun oleh Beck et al. (1979) yang diberi nama Scale for Suicide Ideation. Beck Scale for Suicide Ideation ini telah terdaftar dengan singkatan BSS (Beck, 1991). BSS digunakan untuk mengukur intensitas niat bunuh diri secara sadar atau keinginan untuk merusak diri sendiri. Ide bunuh diri ini juga 
mencangkup "ancaman bunuh diri" yang telah diekspresikan dalam bentuk perilaku terbuka atau diucapkan kepada orang lain. Beck et al. (1979) pada awalnya merancang skala ini dengan 30 butir kemudian menghilangkan butir-butir tersebut dikarenakan adanya tumpang tindih antara satu butir dengan butir lainnya, atau sulit digunakan, atau sulit dinilai. Pada akhirnya BSS terdiri dari 19 butir.

BSS terdiri dari 19 butir dengan intensitas mulai dari 0 sampai 2 dengan rentang skor yaitu 0 sampai 38 (Beck et al., 1979). Dalam penelitian yang dilakukan oleh Steer et al. (1993) disebutkan bahwa 5 butir pertama dalam BSS dapat digunakan untuk mengidentifikasi ide bunuh diri. Apabila individu memberikan peringkat 0 pada 5 butir pertama, mengungkapkan bahwa individu tersebut tidak memiliki niat untuk bunuh diri. Individu yang memberikan peringkat 0 pada butir ke-1 dan ke-4 yang terdapat pada indikator active suicidal desire dan butir ke-5 pada indikator passive suicidal desire, berarti individu tersebut tidak adanya upaya untuk bunuh diri dan adanya tindakan untuk menyelamatkan hidup apabila dihadapkan pada situasi yang mengancam dirinya. Apabila individu tersebut memberikan peringkat 0 pada ke- 5 butir pertanyaan pertama, individu tersebut tidak perlu mengisi 14 butir sisanya yang membahas mengenai rencana dan sikapnya dalam upaya bunuh diri.

Batterham et al. (2015) mengemukakan bahwa BSS memiliki konsistensi internal dengan range 0,89 sampai 0,97 sehingga dapat dikategorikan good to excellent. Tes retest dengan kategori yang sama mendapatkan rentang nilai 0.54-0.88. Concurrent validity sebesar 0,90-0,94. BSS sendiri telah diterjemahkan ke dalam, yaitu Bahasa Belanda (de Beurs et al., 2014), Bahasa Urdu yang merupakan Bahasa Nasional Negara Pakistan (Ayub, 2008), Bahasa Jerman (Kliem et al., 2017), Bahasa Korea, Cina, Prancis, Persia, Melayu, dan Norwegia (Kliem et al., 2017).

Kualitas dari alat ukur yang digunakan dapat menggambarkan konstruk teoritis yang digunakan sebagai dasar operasionalisasi yang merujuk pada validitas konstruk. Hal ini dapat disimpulkan bahwa validitas konstruk merupakan penilaian terhadap seberapa baik peneliti dalam merumuskan teori ke dalam alat ukurnya (Widodo, 2006). Validitas konstruk terbagi menjadi 2 yaitu exploratory factors analysis (EFA) dan confirmatory factor analysis (CFA). EFA digunakan untuk memperkirakan atau mengekstraksi faktor atau memutuskan berapa banyak faktor sehingga dapat ditafsirkan (Swerdlik, 2009). CFA merupakan jenis pemodelan dari SEM (Structural Equation Modeling). SEM digunakan untuk meminimumkan perbedaan antara kovarian yang diprediksi oleh model yang dikonsepkan (Idulfilastri, 2018). CFA berkaitan dengan model pengukuran hubungan antara ukuran atau indikator yang diamati dengan variabel atau faktor laten (Brown, 2014).

BSS pada awalnya diduga memiliki lima indikator, kemudian dilakukan analisis faktor pada penelitian yang dilakukan oleh Beck et al. (1979). Lima indikator tersebut adalah active suicidal desire, planning atau preparation, passive suicidal desire, concealment, dan intensity of suicidal ideation (Holden \& DeLisle, 2005). Hasil yang didapatkan adalah dari ke lima indikator tersebut, tiga diantaranya bermakna secara psikologis sedangkan dua indikator lainnya sulit untuk ditafsirkan. Oleh sebab itu, terdapat tiga indikator yang dimiliki oleh BSS. Indikator tersebut adalah active suicidal desire, preparation, dan passive suicidal desire.

Penelitian lainnya dilakukan oleh Steer et al. (1993) didapatkan hasil bahwa indikator dalam BSS terdiri dari 3 indikator yaitu desire for death atau passive suicidal desire, preparation for suicide, dan active suicidal desire. Pada penelitian yang dilakukan oleh Holden \& DeLisle (2005) menganalisis indikator dalam BSS terdiri dari 2 indikator yang mereplikasi dari temuan Beck et 
al. pada tahun 1997. Indikator atau skala preparation dan motivation menunjukkan tingkat konsistensi internal dan convergent validity yang dapat diterima.

Pada penelitian yang dilakukan di Indonesia, indikator yang digunakan dalam BSS beragam. Ada sebanyak 2 peneliti yang menggunakan tiga indikator pada alat ukur Beck Scale for Suicide Ideation (BSS), 1 peneliti yang menggunakan lima indikator dalam BSS, serta 1 peneliti yang hanya menggunakan alat ukur BSS tanpa menjelaskan indikator yang digunakan.

Berdasarkan penjelasan di atas, dapat disimpulkan bahwa banyaknya kasus bunuh diri terjadi di Indonesia pada saat ini terutama pada usia dewasa awal sehingga perlunya pemahaman mengenai ide bunuh diri. Pemahaman mengenai ide bunuh diri ini membuat beberapa peneliti memunculkan skala ide bunuh diri. Salah satunya adalah Beck et al. (1979) yang mengembangkan alat ukur bernama Beck Scale for Suicide Ideation (BSS) disusun untuk mengukur intensitas niat bunuh diri secara sadar atau keinginan untuk merusak diri sendiri. Di Indonesia terdapat beberapa peneliti yang menggunakan BSS untuk mengukur ide bunuh diri dengan menggunakan tiga indikator dan lima indikator. Hal tersebut membuat peneliti tertarik untuk menguji struktur faktor dalam konstruk Beck Scale for Suicide Ideation yang sesuai dengan dewasa awal di Indonesia.

\section{Rumusan Masalah}

Apakah struktur faktor dalam kunstruk Beck Scale for Suicide Ideation sesuai pada dewasa awal di Indonesia yang memiliki ide bunuh diri?

\section{METODE PENELITIAN}

Penelitian ini menggunakan desain penelitian non-experimental dengan jenis pendekatan penelitian kuantitatif. Pendekatan ini menguji struktur faktor dari skala ide bunuh diri yaitu BSS. Partisipan akan diberikan skala dari BSS yang telah diterjemahkan oleh peneliti ke dalam Bahasa Indonesia. Partisipan yang sama juga diberikan BDI (Beck Depression Inventory) untuk menyeleksi subjek dengan major depressive disorder. Hasil yang didapat digunakan untuk menguji struktur faktor. Struktur faktor didapatkan dari pengujian EFA (Exploratory Factor Analysis), dan CFA (Confirmatory Factor Analysis). Pengujian EFA menggunakan program SPSS 25, sedangkan CFA menggunakan program Lisrel 8.80. Tahapan dalam pengujian EFA adalah data diinput kemudian diproses menggunakan SPSS 25. Data yang dilihat adalah nilai KMO (Kaiser Meyer Olkin) dan Bartlett's Test dengan nilai sig. < 0,05, nilai anti image matrices, dan communalities sig. >0,05, dan total variance explained untuk mengetahui indikator yang ada. Setelah menguji EFA, kemudian menguji CFA dengan tahap spesifikasi model, pengumpulan data, program pembuatan, menjalankan program SIMPLIS dan analisis hasil, uji kecocokan (fit) (Wijanto, 2008).

\section{Partisipan}

Partisipan dalam penelitian ini terdapat 158 partisipan. Sebanyak 100 partisipan memiliki ide bunuh diri, sedangkan 58 partisipan lainnya tidak memiliki ide bunuh diri. Partisipan yang tidak memiliki ide bunuh diri berjenis kelamin laki-laki sebanyak 16 partisipan sedangkan yang berjenis kelamin perempuan sebanyak 42. Partisipan yang memiliki ide bunuh diri pada jenis kelamin lakilaki sebanyak 10, dan perempuan sebanyak 90. Partisipan yang berusia 22 tahun sebanyak delapan partisipan yang tidak memiliki ide bunuh diri dan sebanyak 17 partisipan yang memiliki ide bunuh diri. Partisipan yang berusia 23 tahun sebanyak 11 partisipan yang tidak memiliki ide bunuh diri dan 12 partisipan yang memiliki ide bunuh diri. Partisipan yang berusia 24 tahun sebanyak 12 partisipan yang tidak memiliki ide bunuh diri dan 19 partisipan yang memiliki ide bunuh diri. Partisipan yang berusia 25 tahun sebanyak sembilan partisipan yang tidak memiliki ide bunuh diri, 
dan 23 partisipan yang memiliki ide bunuh diri. Pada partisipan yang berusia 26 tahun sebanyak sembilan partisipan yang memiliki tidak memiliki ide bunuh diri dan memiliki ide bunuh diri dengan jumlah yang sama. Partisipan yang tidak memiliki ide bunuh diri sebanyak empat partisipan dan sebanyak 13 partisipan yang memiliki ide bunuh diri berusia 27 tahun. Pada partisipan yang berusia 28 tahun sebanyak lima partisipan yang tidak memiliki ide bunuh diri, dan sebanyak tujuh partisipan memiliki ide bunuh diri. Partisipan yang memiliki ide bunuh diri sebanyak 51 partisipan yang memiliki ide bunuh diri pada tingkat yang rendah, pada tingkat yang tinggi sebanyak 39 partisipan, dan sebanyak 10 partisipan memiliki tingkat ide bunuh diri yang sangat tinggi.

\section{Instrumen Penelitian}

Instrumen penelitian menggunakan skala dari Beck Scale for Suicide Ideation (BSS) (Beck et al., 1979) yang telah diterjemahkan oleh peneliti ke dalam Bahasa Indonesia dengan 19 butir digunakan untuk mengukur ide bunuh diri pada individu dewasa awal. Validitas dari 19 butir 0,643 sampai 0,913 dinyatakan memiliki validitas yang baik. Pada 19 butir tersebut memiliki reliabilitas 0,963 berarti memiliki korelasi tinggi sekali.

Beck Depression Inventory (BDI-II) untuk menyeleksi individu dengan major depressive disorder yang telah diterjemahkan ke dalam Bahasa Indonesia oleh Ginting et al. (2013) untuk individu yang berusia lebih dari 13 tahun dengan 21 butir. Validitas konstruk yang signifikan dan berkorelasi dengan DS $14(\mathrm{r}-0,5, \mathrm{p}<0,01)$ dan BAI $(\mathrm{r}=0,52, \mathrm{p}<0,01)$, serta berkorelasi negatif dengan MSPSS $(r=0,30, p<0,01)$ dan LOT-R $(r=0,46, p<0,01)$. BDI-II memiliki nilai reliabilitas sebesar $\alpha=0,91$.

\section{Prosedur}

Partisipan diberikan BDI dan skala BSS. Tahap pertama data diolah menggunakan teknik EFA (Exploratory Factor Analysis) untuk menguji butir-butir dalam Beck Scale for Suicide Ideation yang positif dan signifikan terhadap konstruk. Pada tahap ke-2 yang diinput ke dalam SPSS 25 diubah menjadi Simplis dan diolah menggunakan program Lisrel 8.80. Data diuji menggunakan teknik CFA (Confirmatory Factor Analysis) yang akan menghasilkan butir-butir valid terhadap konstruk yang disebut CFA first order. Pengujian CFA untuk menguji hubungan konstruk yang membangun BSS disebut CFA second order. Data akan diuji kecocokan atau goodness of fit untuk mendapatkan pemodelan yang sesuai dengan hipotesis.

\section{HASIL DAN PEMBAHASAN}

Hasil pengujian dengan menggunakan EFA yang menghasilkan 3 komponen terdiri dari komponen 1 memiliki nilai sebesar $11,083 / 19 * 100 \%$ sehingga menghasilkan 58,331. Komponen ke 2 memiliki nilai sebesar 1, 273/19*100\% sehingga menghasilkan 6,699. Pada komponen ke 3 memiliki nilai sebesar 0,941/19*100\% sehingga menghasilkan nilai 4,950. Apabila komponen 1 hingga komponen ke 3 digabungkan maka dapat menjelaskan 69,980\% variansi dari faktor yang dibentuk. 


\section{Tabel 1}

Component Matrix

\begin{tabular}{cccc}
\hline \multirow{2}{*}{ Item } & \multicolumn{3}{c}{ Component } \\
& 1 & 2 & 3 \\
\hline Item 1 & 0.794 & 0.309 & 0.099 \\
Item 6 & 0.760 & 0.178 & 0.296 \\
Item 7 & 0.744 & 0.366 & 0.264 \\
Item 9 & 0.670 & 0.160 & 0.313 \\
Item 8 & 0.662 & 0.474 & 0.141 \\
Item 3 & 0.660 & 0.423 & 0.297 \\
Item 2 & 0.655 & 0.541 & 0.229 \\
Item 16 & 0.634 & 0.129 & 0.473 \\
Item 15 & 0.607 & 0.541 & 0.353 \\
Item 4 & 0.605 & 0.603 & 0.277 \\
Item 11 & 0.168 & 0.831 & 0.213 \\
Item 5 & 0.359 & 0.778 & 0.014 \\
Item 19 & 0.128 & 0.760 & 0.352 \\
Item 10 & 0.524 & 0.556 & 0.052 \\
Item 18 & 0.487 & 0.529 & 0.426 \\
Item 13 & 0.451 & 0.454 & 0.442 \\
Item 17 & 0.148 & 0.175 & 0.869 \\
Item 14 & 0.530 & 0.203 & 0.555 \\
Item 12 & 0.486 & 0.244 & 0.546 \\
\hline
\end{tabular}

Komponen 1 terdiri dari 10 butir yaitu butir nomor 1 sebesar 0,794, butir nomor 2 sebesar 0,655, butir nomor 3 sebesar 0,660, butir nomor 4 sebesar 0,605, butir nomor 6 sebesar 0,760, butir nomor 7 sebesar 0,744 , butir nomor 8 sebesar 0,662, butir nomor 9 sebesar 0,670 , butir nomor 15 sebesar 0,607 , dan butir nomor 16 sebesar 0,634 .

Komponen ke 2 terdiri dari 6 butir yaitu butir nomor 5 sebesar 0,778 , butir nomor 10 sebesar 0,556, butir nomor 11 sebesar 0,831, butir nomor 13 sebesar 0,454, butir nomor 18 sebesar 0,529, dan butir nomor 19 sebesar 0,760. Komponen ke 3 terdiri dari 3 butir yaitu butir nomor 12 sebesar 0,869 , butir nomor 14 sebesar 0,555 , dan butir nomor 17 sebesar 0,869 .

Komponen 1, ke 2 dan ke 3 memiliki nilai korelasi sebesar 0,709 untuk komponen 1, komponen ke 2 -0,799, dan komponen ke 3 0,774. Hal ini berarti ke 3 komponen yang memiliki korelasi diatas 0,5 sehingga tepat dalam merangkum ke 19 butir yang ada. Hal ini yang membuat peneliti menetapkan bahwa BSS memiliki 3 komponen yaitu active suicidal desire, passive suicidal desire, dan preparation.

Pada komponen 1 merupakan indikator active suicidal desire terdiri dari 10 butir, indicator passive suicidal desire merupakan komponen ke 2 terdiri dari 6 butir, dan indicator preparation merupakan komponen 3 terdiri dari 3 butir. Hasil pengujian pada 19 butir dinyatakan valid sebagai berikut: 


\section{Tabel 2}

Hasil Pengujian Konstruk BSS dengan Indikator Valid Metode CFA

\begin{tabular}{|c|c|c|c|c|c|c|}
\hline Indikator & Butir & Factor Loading & $t$-value & Standard error & Signifikan & $\mathrm{R}^{2}$ \\
\hline \multirow{10}{*}{ Active Suicidal Desire } & 1 & 0,80 & 11.88 & 0,034 & $\mathrm{~V}$ & 63 \\
\hline & 2 & 0,89 & 14,06 & 0,048 & $\mathrm{~V}$ & 79 \\
\hline & 3 & 0,84 & 12,85 & 0,044 & V & 70 \\
\hline & 4 & 0,86 & 13,20 & 0,048 & V & 73 \\
\hline & 6 & 0,78 & 11,47 & 0,045 & $\mathrm{~V}$ & 60 \\
\hline & 7 & 0,88 & 13,85 & 0,038 & $\mathrm{~V}$ & 77 \\
\hline & 8 & 0,79 & 11,70 & 0,047 & $\mathrm{~V}$ & 62 \\
\hline & 9 & 0,69 & 9,66 & 0,031 & $\mathrm{~V}$ & 47 \\
\hline & 15 & 0,84 & 12,86 & 0,045 & V & 70 \\
\hline & 16 & 0,68 & 9,61 & 0,033 & V & 47 \\
\hline \multirow{7}{*}{ Passive Suicidal Desire } & 5 & 0,82 & 11,82 & 0,044 & V & 66 \\
\hline & 10 & 0,68 & 9,20 & 0,047 & $\mathrm{~V}$ & 46 \\
\hline & 11 & 0,80 & 11,42 & 0,064 & V & 63 \\
\hline & 13 & 0,65 & 8,60 & 0,052 & V & 42 \\
\hline & 18 & 0,74 & 10,25 & 0,042 & V & 55 \\
\hline & 19 & 0,75 & 10,48 & 0,058 & V & 56 \\
\hline & 12 & 0,82 & 10,14 & 0,045 & V & 67 \\
\hline \multirow[t]{2}{*}{ Preparation } & 14 & 0,78 & 9,61 & 0,043 & V & 60 \\
\hline & 17 & 0,62 & 7,66 & 0,039 & $\mathrm{~V}$ & 38 \\
\hline
\end{tabular}

Note. Factor Loading $>0,5, t$-value $>1,96, \mathrm{~V}$ signifikan, $\mathrm{X}$ tidak signifikan

Pada indikator active suicidal desire jika dilihat dari kontribusi butir terhadap indikator, terlihat bahwa butir ke 2, 5, dan 12 dengan $\mathrm{R}^{2} 79 \%$, 66\%, dan 67\%, merupakan butir yang memiliki kontribusi paling besar terhadap indikator active suicidal desire, passive suicidal desire, dan preparation. 19 butir tidak bermuatan negatif, sehingga semakin tinggi nilai pada butir tersebut, maka semakin tinggi pula nilai pada indikator yang diukur seperti pada tabel 2.

Pada Tabel 3. merupakan hasil pengujian model dari 3 indikator menggunakan CFA. Indikator active suicidal desire memiliki 3 indeks penilaian yang tidak fit. Menurut Wijanto (2008), model dapat dikatakan good fit apabila memenuhi 10 kriteria, sedangkan bad fit apa bila kurang memenuhi 3 kriteria. Pada indikator active suicidal desire memenuhi 12 kriteria dari 15 kriteria, sehingga dapat dikatakan model pada indikator active suicidal desire adalah good fit.

Pada indikator passive suicidal desire memenuhi ke 15 kriteria sehingga dapat dikatakan bahwa model tersebut good fit. Pada indikator preparation terdapat nilai P-value sebesar 1,00 sehingga dapat dikatakan bahwa model tersebut memiliki prefect fit. Pada konsep VE atau variance extracted merupakan jumlah total variance yang diukur sehingga memiliki kesamaan dengan konstruksi yang ada (Hair Jr et al., 2014). Nilai VE pada indikator active suicidal desire sebesar 0,94 (94\%). Hal ini berarti, semua butir mengukur 1 konstruksi yang sama dan juga sedikitnya jumlah kesalahan atau error pengukuran. Jadi, 10 butir pada indikator active suicidal desire samasama mengukur keinginan untuk bunuh diri.

Nilai VE pada indikator passive suicidal desire sebesar 1,00 (100\%). Hal ini berarti, 6 butir tersebut sama-sama mengukur 1 konstruksi yang sama yaitu langkah-langkah untuk menyelamatkan hidup. Nilai VE pada indikator preparation sebesar 0,93 (93\%). Hal ini berarti 3 butir yang ada memiliki kesalahan atau error yang sedikit dan sama-sama mengukur 1 konstruksi yaitu persiapan untuk mengakhiri hidup. 
Model pada 3 indikator memenuhi 10 indeks penilaian yang dikategorikan good fit dan 2 indeks penilaian yang dikategorikan marginal fit, dan 3 indeks penilaian yang dikategorikan not fit. Menurut Wijanto (2008), model dikatakan good fit apabila memiliki minimal 10 indeks penilaian yang good fit. Berdasarkan hal tersebut, model BSS dapat dikatakan good fit.

\section{Tabel 3}

Hasil Pengujian 3 Indikator Metode CFA

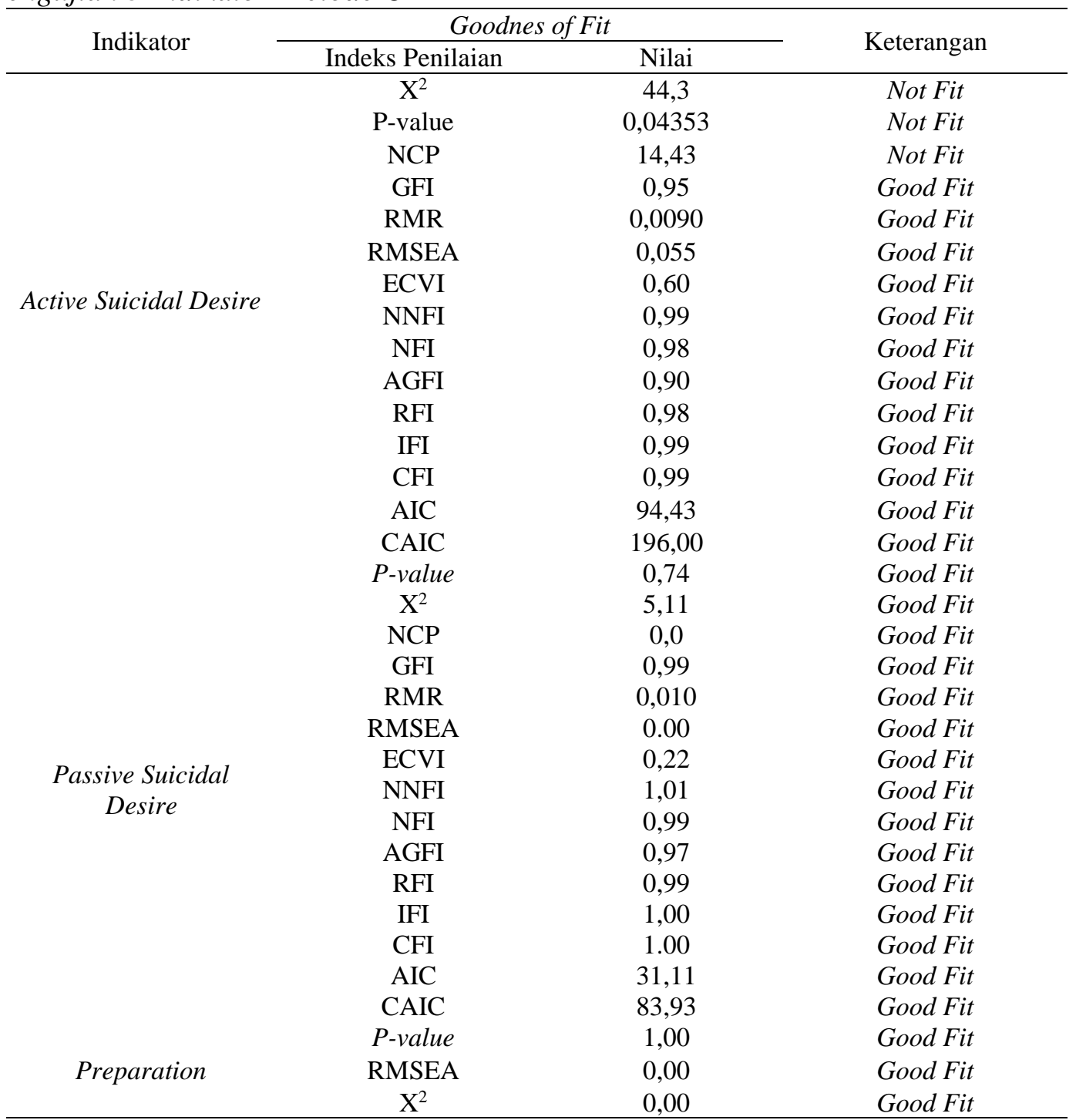




\section{Tabel 4}

Hasil Pengujian Konstruk BSS

\begin{tabular}{cccc}
\hline \multirow{3}{*}{ Konstruk } & \multicolumn{2}{c}{ Goodness of Fit } & \\
\cline { 2 - 3 } & Indeks & Nilai & Keterangan \\
& Penilaian & & \\
\hline \multirow{4}{*}{ X } & 178,85 & Not Fit \\
& P-value & 0,0244 & Not Fit \\
NCP & 49,85 & Not Fit \\
& GFI & 0,89 & Marginal Fit \\
& RMR & 0,014 & Good Fit \\
& RMSEA & 0,050 & Good Fit \\
& ECVI & 1,92 & Good Fit \\
& NNFI & 0,99 & Good Fit \\
& NFI & 0,98 & Good Fit \\
& AGFI & 0,84 & Marginal Fit \\
& RFI & 0,97 & Good Fit \\
& IFI & 0,99 & Good Fit \\
& CFI & 0,99 & Good Fit \\
& AIC & 300,85 & Good Fit \\
& CAIC & 548,67 & Good Fit \\
\hline
\end{tabular}

Pada ke 3 indikator dapat terlihat bahwa ke 3 indikator tersebut memiliki korelasi satu sama lain. Pada indikator active suicidal desire memiliki korelasi sebesar 0,97 terhadap passive suicidal desire, passive suicidal desire memiliki korelasi sebesar 0,84 terhadap preparation, dan preparation memiliki korelasi sebesar 0,86 terhadap active suicidal desire dan begitu pula sebaliknya.

Tahap selanjutnya adalah menganalisis construct reliability (CR). Konsep CR dihitung dari jumlah kuadrat dari factor loadings untuk setiap konstruk dan jumlah error variance untuk setiap konstruk (Hair Jr et al., 2014). Nilai dari CR yang baik adalah >0,70. Pada konstruk BSS menghasilkan nilai CR sebesar 1,00. Hal ini terlihat bahwa BSS memiliki validitas internal yang baik, serta setiap butir mewakili konstruk yang ada.

\section{KESIMPULAN DAN SARAN}

Struktur faktor dalam konstruk Beck Scale for Suicide ideation (BSS) dapat diterapkan pada dewasa awal yang memiliki ide bunuh diri dengan menggunakan tiga faktor dengan 19 butir yang valid. Butir-butir dalam BSS merupakan butir yang positif dan signifikan terhadap konstruk ide bunuh diri. Hal ini terlihat dari pengolahan data dengan menggunakan EFA. Berdasarkan pengujian dengan menggunakan EFA, didapatkan 3 indikator. Pada indikator pertama terdiri dari 10 butir, pada indikator ke 2 terdiri dari 6 butir, dan pada indikator ke 3 terdiri dari 3 butir.

Setelah pengujian dengan metode EFA, dilanjutkan dengan menggunakan metode CFA. Berdasarkan penggunaan CFA, diketahui butir tersebut signifikan dan positif terlihat dari Tabel 4.4. Hal ini berarti, semakin tinggi nilai yang diberikan oleh individu mengartikan bahwa semakin tinggi pula ide bunuh diri pada individu tersebut untuk melakukan bunuh diri.

Konstruk dalam BSS dapat dikategorikan good fit terdapat data subjek dewasa awal di Indonesia. Konstruk BSS sendiri signifikan dalam membangun tes BSS. Hal ini terlihat dari nilai nilai CR sebesar 1,00. Hal ini berarti, BSS memiliki validitas internal yang baik, sehingga setiap butir dalam BSS mewakili konstruk yang ada. Nilai VE yang didapatkan per indikator juga memperlihatkan bahwa butir-butir dalam indikator mengukur indikator masing-masing. 
Konstruk BSS signifikan dalam membangun BSS. Hal ini terlihat dari model BSS. Model ini dapat dikategorikan merupakan model yang good fit. Hal ini membuat konstruk BSS terdiri dari 3 indikator yaitu active suicidal desire, passive suicidal desire, dan preparation. Konstruk yang ada juga saling berhubungan satu sama lain. BSS sendiri dalam penelitian ini terdiri dari 19 item.

Pada penelitian selanjutnya, dapat mengadaptasi alat ukur BSS ke dalam Bahasa Indonesia sehingga alat ukur ini menjadi alat ukur yang baku. Selain itu, dapat juga menggunakan alat ukur ini pada sampel yang berbeda seperti remaja dan menggunakan sampel yang lebih besar. Hal ini diharapkan dapat menambah kemampuan generalisasi alat ukur untuk mengukur ide bunuh diri. Penelitian ini diharapkan dapat menjadi sumbangan alat ukur untuk dapat mengukur tingkat ide bunuh diri pada individu yang memiliki ide bunuh diri sehingga dapat membantu pemberian intervensi psikologi dan penanganan psikologis yang cepat dan tepat.

\section{REFERENSI}

Adzkia, A. (2019). Tiap satu jam, satu orang Indonesia bunuh diri. Beritagar.Id. https://beritagar.id/artikel/berita/tiap-satu-jam-satu-orang-indonesia-bunuh-diri

American Psychiatric Association. (2013). Diagnostic and statistical manual of mental disorder edition "dsm 5." American Psychiatrical Publishing.

Ayub, N. (2008). Validation of the Urdu translation of the beck scale for suicide ideation. Assessment, 15(3), 287-293. https://doi.org/10.1177/1073191107312240

Batterham, P. J., Ftanou, M., Pirkis, J., Brewer, J. L., Mackinnon, A. J., Beautrais, A., Kate Fairweather-Schmidt, A., \& Christensen, H. (2015). A systematic review and evaluation of measures for suicidal ideation and behaviors in population-based research. Psychological Assessment, 27(2), 501-512. https://doi.org/10.1037/pas0000053

Beck, A. T. (1991). Beck Scale for Suicide Ideation ${ }^{\circledR}$ (BSS®). PsychCorp. https://www.pearsonclinical.ca/en/products/product-master/item-136.html

Beck, A. T., Kovacs, M., \& Weissman, A. (1979). Assessment of suicidal intention: The scale for suicide ideation. Journal of Consulting and Clinical Psychology, 47(2), 343-352. https://doi.org/10.1037/0022-006X.47.2.343

Beck, A. T., Steer, R. A., Beck, J. S., \& Newman, C. F. (1993). Hopelessness, depression, suicidal ideation, and clinical diagnosis of depression. Suicide and Life-Threatening Behavior, 23(2), 139-145. https://doi.org/10.1111/j.1943-278X.1993.tb00378.x

Brown, T. A. (2014). Confirmatory factor analysis for applied research. Guilford Publications.

CNN Indonesia. (2019, September 10). WHO: Tiap detik ada satu orang tewas bunuh diri di dunia. CNNIndonesia.com. https://www.cnnindonesia.com/gaya-hidup/20190910023019-255428942/who-tiap-detik-ada-satu-orang-tewas-bunuh-diri-di-dunia

Damarjati, D. (2019, Januari 19). Tingkat bunuh diri indonesia dibanding negara lain. detik.com. https://news.detik.com/berita/d-4391681/tingkat-bunuh-diri-indonesia-dibanding-negaranegara-lain

Databoks. (2016, Desember 22). Di provinsi mana banyak orang bunuh diri? databoks. https://databoks.katadata.co.id/datapublish/2016/12/22/jawa-tengah-provinsi-dengankasus-bunuh-diri-terbanyak-di-indonesia

de Beurs, D. P., Fokkema, M., de Groot, M. H., de Keijser, J., \& Kerkhof, A. J. F. M. (2014). Longitudinal measurement invariance of the Beck Scale for Suicide Ideation. Psychiatry Research, 225(3), 368-373. https://doi.org/10.1016/j.psychres.2014.11.075 
Ginting, H., Näring, G., Van Der Veld, W. M., Srisayekti, W., \& Becker, E. S. (2013). Validating the beck depression inventory-II in Indonesia's general population and coronary heart disease patients. International Journal of Clinical and Health Psychology, 13(3), 235-242. https://doi.org/10.1016/S1697-2600(13)70028-0

Hair Jr, J. F., Black, W. C., Babin, B. J., \& Anderson, R. E. (2014). Multivariate data analysis (7th ed.). Pearson New International Edition.

Holden, R. R., \& DeLisle, M. M. (2005). Factor analysis of the beck scale for suicide ideation with female suicide attempters. Assessment, 12(2), 231-238. https://doi.org/10.1177/1073191105274925

Idulfilastri, R. M. (2018). Pengujian konstruk tes potensi manajerial berdasarkan validitas butir dengan metode factor analysis. Jurnal Muara Ilmu Sosial, Humaniora, Dan Seni, 2(1), 189-197. https://doi.org/10.24912/jmishumsen.v2i1.1597

Jayani, D. H. (2019, November 9). Berapa angka bunuh diri di indonesia? databoks. https://databoks.katadata.co.id/datapublish/2019/09/11/berapa-angka-bunuh-diri-diindonesia

Kliem, S., Lohmann, A., Mößle, T., \& Brähler, E. (2017). German beck scale for suicide ideation (BSS): Psychometric properties from a representative population survey. BMC Psychiatry, 17(1), 1-8. https://doi.org/10.1186/s12888-017-1559-9

Perlman, C., Neufeld, E., Martin, L., Goy, M., \& Hirdes, J. P. (2011). Suicide risk assessment inventory: A resource guide for Canadian health care organizations. Ontario Hospital Association and Canadian Patient Safety Institute. https://www.patientsafetyinstitute.ca/en/toolsResources/SuicideRisk/Documents/Suicide \%20Risk\%20Assessment\%20Guide.pdf

Reynolds, W. M. (1991). Psychometric characteristics of the adult suicidal ideation questionnaire in college students. Journal of Personality Assessment, 56(2), 289-307. https://doi.org/10.1207/s15327752jpa5602_9

Steer, R. A., Rissmiller, D. J., Ranieri, W. F., \& Beck, A. T. (1993). Dimensions of suicidal ideation in psychiatric inpatients. Behaviour Research and Therapy, 31(2), 229-236. https://doi.org/10.1016/0005-7967(93)90090-H

Susilawati, D. (2018, Oktober 16). Angka bunuh diri di anak muda meningkat. republika. https://www.republika.co.id/berita/gaya-hidup/info-sehat/18/10/16/pgoqeo328-angkabunuh-diri-di-anak-muda-meningkat

Swerdlik, C. (2009). Psychological testing and assessment: An introduction to tests and measurement (7th ed.). McGraw-Hill.

Widodo, P. B. (2006). Reliabilitas dan validitas konstruk skala konsep diri untuk mahasiswa indonesia. Jurnal Psikologi Universitas Diponegoro, 3(1), 1-9. https://doi.org/10.14710/jpu.3.1.1\%20-\%209

Wijanto, S. H. (2008). Structural equation modeling dengan Lisrel 8.8: konsep dan tutorial. Graha Ilmu. 